\title{
Personality traits and select socio-demographic variables as predictors of military morale: longitudinal research in the Estonian defence forces
}

DOI 10.2478/jms-2021-0003

Received: June 01, 2020; Accepted: March 08, 2021

\begin{abstract}
Military morale is a concept widely used to describe the motivational element of soldiers' will to fight or "the energy that drives soldiers to perform qualitatively better in stressful conditions, characterised by enthusiasm and persistence when engaging in collective, i.e. unit-level activities". This longitudinal study explored the interlinkages between perceptions of military morale, the Big Five personality traits and select socio-demographic characteristics among the conscripts of the Estonian Defence Forces and predicting directly measurable individual and collective types of military morale. Moreover, the fluctuation of military morale over the training cycle of conscript service (11 months) was tracked. The findings indicate that at the start of military service, individual morale has a low or medium statistically significant correlation with conscripts' personality traits, with Conscientiousness and Neuroticism demonstrating the strongest relations; however, the correlation with Neuroticism was negative. Additionally, when viewed throughout the course of the entire training cycle, the morale demonstrated a U-shaped progression, i.e. high at the beginning, dropping in the middle and rising back up at the end of military service. At the same time, socio-demographic variables demonstrated little or non-significant role in predicting individual or collective morale. The results indicate that morale fluctuates over time and is affected by personal characteristics. For practitioners, these results could help to reinforce the positive impact of morale on collective and individual performances.
\end{abstract}

\footnotetext{
*Corresponding author: Antek Kasemaa, Estonian Military Academy, Chair of Leadership and Pedagogy, Riia 12, 51010 Tartu, Estonia; Tallinn University, School of Natural Sciences and Health, 10120 Tallinn, Estonia; E-mail: antek.kasemaa@tlu.ee

Ülle Säälik, Estonian Military Academy, Chair of Leadership and Pedagogy, Riia 12, 51010 Tartu, Estonia
}

Keywords: military morale, personality, the Big Five, socio-demographic variables

\section{Introduction}

Military morale has been considered one of the most important contributors to improved performance in the military environment (Manning 1991; Ivey 2014; Fennell 2014; Britt and Dickinson 2006; Reed et al. 2011: 203). Throughout history, both practitioners and researchers have sought to define and conceptualize the phenomenon of military morale. However, what it is or how it is related to individual or collective performance is still not fully clear. Generally, the term "morale" has been used together with other constructs that have a similar meaning (see e.g. Hardy 2009: 24; Ingraham and Manning 1981; Peterson et al. 2008; Shamir et al. 2000).

The most widely used definition of military morale has been offered by Manning (1991: 455) as "the enthusiasm and persistence with which a member of a group engages in the prescribed activities of that group". Britt and Dickinson (2006: 162) elaborate it further as "a service member's level of motivation and enthusiasm for accomplishing mission objectives", arguing that their definition captures the elements of military morale better, especially in the case of individuals participating in military operations. Either Manning's definition has been used for military morale, as by van Boxmeer et al. (2007) and Jonsson et al. (2010), or Britt and Dickinson's definition has been used, e.g. by Dyches et al. (2017) and Britt et al. (2007).

The authors of this study propose a definition and model of military morale as a variable that gives a service member energy that drives him/her to perform qualitatively better in stressful conditions and that which is characterized by enthusiasm and persistence with which individual unit members engage in the tasks assigned to 
the unit as a whole/collective (Kasemaa and Säälik 2021). In this context, a unit could be a team, squad, platoon, company or any other military equivalent. Consequently, we approach military morale as both an individual-level and a collective (i.e. unit-level)-level construct, i.e. as a variable that describes the individuals within the social context and sees units as social entities.

Some previous studies have attempted to associate morale with certain psychological constructs, such as individual personality patterns (Herrera 2012), or with positive and negative affectivity of various aspects of morale (e.g. work engagement and burnout) (Kasemaa and Säälik 2021; Steger et al. 2013). This study seeks to answer whether directly measured morale could be predicted by individual characteristics, such as personality traits or socio-demographic factors, to provide a better understanding of why some service members are more likely to be enthusiastic about and more engaged in their work-related activities. Furthermore, it might contribute to the development of interventions to promote military morale and improve performance as a result.

Overall, the aim of this study is to explore the role of individual characteristics (i.e. personality traits and socio-demographic variables) in predicting military morale, at both the individual and collective levels. Consequently, the principal research question seeks to ascertain whether personality or socio-demographic characteristics contribute to the fluctuation of military morale and to what extent.

\section{Defining military morale}

The definition and conceptualization of morale as an individual or collective psychological phenomenon has gone through several iterations over time, studied in both the military context and outside it (Gal 1986; Motowidlo and Borman 1977, 1978; Britt et al. 2007). Most commonly, morale has been defined by enthusiasm (Britt et al. 2007; Cotton and Hart 2003; Manning 1991; Shamir et al. 2000), general feelings of satisfaction (Motowidlo and Borman 1977; Manning 1994; Hardy 2009) and motivation to achieve group objectives (Motowidlo and Borman 1977; Britt and Dickinson 2006); or through well-being based on self- and group confidence (Gal 1986) or self- and/or collective efficacy (Hardy 2009); but also through the cognitive, emotional and motivational stance towards group goals and tasks (Peterson et al. 2008). Usually, it comprises such characteristics as confidence, optimism, enthusiasm and loyalty, as well as a sense of common purpose. Thus, almost all definitions of morale incorporate several self-determined psychological elements related to feelings or state of mind, e.g. energy and enthusiasm, but also factors related to goals and groups.

Britt and Dickinson (2006) examined military morale primarily as a unidimensional construct, while van Boxmeer et al. (2007) used a multidimensional conceptualization. Furthermore, van Boxmeer et al. (2007) argued that the elements of military morale, such as enthusiasm and persistence, might be very close to the key elements of work engagement (based on Maslach and Leiter's concept of work engagement, comprising energy and involvement) and its opposite - burnout, characterized primarily by exhaustion and cynicism (Maslach and Leiter 1997). This approach has subsequently been used in several empirical studies, e.g. by Chambel et al. (2015), Ivey et al. (2015) and van Boxmeer et al. (2011), and forms the basis for the conceptual model put forward by the authors of this study as well.

Generally, military morale has been found to be positively associated with several psychological and attitudinal variables that contribute to organizational success, such as well-being (Tucker et al. 2005), job satisfaction (Motowidlo and Borman 1978; Tucker et al. 2005), small unit cohesion (Griffith 1988) and collective efficacy (Jex and Bliese 1999), to name a few. Moreover, military morale has been shown to mitigate the effect of job-related stress on performance (Milgram et al. 1989; Britt et al. 2013). Furthermore, morale has been found to be negatively associated with the symptoms of post-traumatic stress disorder (Whitesell and Owens 2012; Dyches et al. 2017). Therefore, it is important to explore how the personal factors of each individual member of an organization affect the overall level of organizational morale.

Whether the phenomenon of morale is primarily an individual- or a group-level characteristic is still under debate. Some studies have found morale to be related to both individuals and groups (Ivey 2014: 9), while others have underlined the role of individuals within those groups (Peterson et al. 2008; Hardy 2009; Britt and Oliver 2013: 49). Considering our definition of military morale as something that gives service members energy and that is characterized by enthusiasm and persistence with which individual members engage in the tasks assigned to their unit, we might conclude that it is primarily an individuallevel construct. However, when individual members believe that their unit is able to manage collectively in stressful situations, it could be a contributor to military morale. This assumption is supported by previous research (Shamir et al. 2000; Chen and Bliese 2002; Britt and Dickinson 2006: 172) and, therefore, it is warranted that some elements of morale should be considered at the 
unit level as well. One possible approach is to look at unit morale as an aggregation of the individual morale of each unit member. This approach is supported by such authors as Ivey (2014: 14) and Euwema et al. (2009).

\section{Personality and military morale}

An individual's personality can be defined as something that makes that person unique, setting them apart from others, ranging from Allport's definition as the psychophysical systems creating a person's characteristic patterns of behaviour, thoughts and feelings (1961: 28); to Child's construct as the more-or-less stable internal factors making one person's behaviour consistent from one time to another and different from the behaviour that other people might manifest in comparable situations (1968: 83); to Funder's suggestion as the individual differences in characteristic patterns of thinking, feeling and behaving, together with the psychological mechanisms (hidden or not) behind those patterns (2001: 2).

Most commonly in use is, however, McCrae and Costa's concept of personality as the way in which people perceive and interpret events, thoughts and feelings in their life (2008: 160). Drawing on those examples, the central idea of a uniquely characteristic pattern of thoughts, feelings and behaviours as someone's more-or-less constant and, therefore, predictable trait has been most recently formulated through perception and interpretation of life events, which leads us to assume that if we can identify measurable personality traits, we should also be able to predict other types of psychological perceptions of life events (e.g. perceived well-being, level of morale, and so on).

The five-factor model of personality, better known as the Big Five, with its acronym OCEAN, describes personality as the framework through which people perceive and interpret events, thoughts and feelings in their life, and it is made up of the following factors: Openness to experience (Ope), Conscientiousness (Con), Extraversion (Ext), Agreeableness (Agr) and Neuroticism (Neu) (Costa and McCrae 1995; McCrae and Costa 2008). Previous studies have found that personality dimensions are closely linked to a variety of organizational variables, such as job satisfaction (Judge et al. 2002), commitment (Erdheim et al. 2006) or counterproductive behaviour (Dalal 2005; Berry et al. 2007). Sinclair and Tucker (2006: 210-211) argue that the role of personality is more important for occupations involving higher intensity of interpersonal interactions, as in the case of the military.

Ope means that the person tends to be curious and creative and needs variety and independence; the person also tends to be quite open to feelings, actions, ideas and values (Costa and McCrae 1992; McCrae and Costa 2008). Ope has been found to have a strong correlation with contextual performance as compared to task performance (Chiaburu et al. 2011), as well as a positive correlation with work engagement (Akhtar et al. 2015; Morgan and de Bruin 2010), whereas it appeared to have a non-significant correlation with burnout (Kim et al. 2007).

Con as a personality trait means that the person is dutiful, self-disciplined, follows rules and ethical principles and tends to be focussed on job involvement (Costa and McCrae 1992; McCrae and Costa 2008). Con has been found to be correlated with, or even be able to predict, both task and contextual performances across most occupations (Sinclair and Tucker 2006; Chiaburu et al. 2011) as well as to work engagement (Bakker et al. 2012).

Ext refers to active, gregarious and excitementseeking people who exhibit high levels of enthusiasm and optimism (Costa and McCrae 1992; McCrae and Costa 2008), with positive relationship to task and contextual performances (Chiaburu et al. 2011) and work engagement (Akhtar et al. 2015; Inceoglu and Warr 2011), while having a negative correlation with exhaustion (Gustafsson et al. 2009; Kim et al. 2007).

Agr means that the person is altruistic, trusting and trustworthy, sensitive towards the needs of others and therefore values a cooperative work environment or tends to develop positive relations with co-workers relatively easily (Costa and McCrae 1992; McCrae and Costa 2008). Agr has shown positive correlation with contextual performance (Ilies et al. 2009; Chiaburu et al. 2011) and with work engagement (Akhtar et al. 2015; Morgan and de Bruin 2010).

Neu is a personality trait that represents a tendency to experience negative emotions. As a result, these people tend to be anxious, depressed, fearful, impulsive and vulnerable (Costa and McCrae 1992; McCrae and Costa 2008). Neu has been shown to have a negative correlation with task and contextual performances (Chiaburu et al. 2011) and a positive one with exhaustion and cynicism (Bühler and Land 2003; Kim et al. 2007; Langelaan et al. 2006).

Thus, while most personality traits are associated with positive emotions and striving towards better performance, we can also see that neurotic people tend to focus on the negative aspects of situations. Moreover, they might also ignore or downplay the feelings of engagement due to their tendency to become easily frustrated and evaluate their personal competencies as well as future prospects negatively, as revealed by research conducted by Kim et al. (2009) and Bakker et al. (2002), who concluded that Neu is the primary personality trait predicting burnout at work. 
Based on the aforementioned studies, it could be assumed that the Big Five personality traits are well suited for describing the level of morale. Based on previous findings, we posit the following hypotheses regarding the effect of the Big Five personality traits on military morale (H1): morale is positively correlated with Con, Ext, Agr and Ope (H1.1); and, morale is negatively correlated with Neu (H1.2).

In addition, previous studies have demonstrated that the Big Five personality traits are able to explain a significant part of subjective well-being (Ryff 1989). Therefore, the similarities between well-being and morale and the differences between individual and collective types of morale (i.e. the first addresses the level of personal morale, while the other portrays the morale of one's fellow unit members or unit-level morale) are considered. Additionally, we might also hypothesize that different personality traits are more strongly related with either individual or collective morale. For example, people who value social relationships (i.e. exhibit a high level of Agr) or those who are happy to express themselves in social contexts (i.e. a high level of Ext) might rate collective morale higher than individual morale, whereas individuals who tend to get anxious quite easily (a high level of Neu) or who value order and discipline (a high level of Con) might rate individual morale more highly. Therefore, we posit that Agr and Ext are more strongly correlated with collective morale (H2.1), while Con and Neu are more strongly correlated with individual morale (H2.2).

\section{Fluctuation of military morale}

Only a few studies that explore military morale over a longer period of time exist, despite the fact that the concept of military morale and its fluctuation has captured the interest of both researchers and practitioners (Britt and Dickinson 2006). For example, Britt et al. (2007) conducted longitudinal research in Kosovo, focussing on long-term associations between morale and depression. Another example that suits our conceptualization of morale is the research conducted by Cremers (2018), studying morale in the Dutch army in the context of deployment. Cremers' findings indicate that, in general, the positive components of morale, such as vigour and dedication, were higher before deployment as compared to during deployment, whereas the opposite was true for burnout (i.e. cynicism and exhaustion) (Cremers 2018).

Furthermore, the research on small unit cohesion suggests that during conscription, military morale may undergo a U-shaped progression. This hypothesis is supported by research conducted by Vaitkus and Griffith (1990), Siebold (1999) and Siebold (2006), who argue that it takes time for unit cohesion to develop, which tends to drop after a certain period of time, and that after a while, it starts increasing again but does not reach the same level as before the drop. Contrarily, Bartone and Adler (1999), as well as Maugen and Litz (2006), have found that the development of unit cohesion follows a reverse-U shape. The research conducted outside the military context seems to indicate that the perception of work engagement and burnout might be quite stable (see e.g. Xanthopoulou et al. 2009; Sonnenchein 2007: 14), although influenced by several organizational variables, such as supportive colleagues, self-efficacy, job autonomy, etc. (see e.g. Salanova et al. 2006; Xanthopoulou et al. 2009; Houkes et al. 2011). Therefore, the authors of this paper argue that military morale is not just an isolated and stable phenomenon but should instead be seen as a dynamic process that changes over time.

So far, there have not been many studies focussing on morale in the Estonian Defence Forces (EDF) and related organizations (Parmak 2010; Kasemaa and Säälik 2021). Beyond Estonia, the majority of research has focussed on professional armies and not on conscription-based ones (see e.g. Ivey et al. 2015; van Boxmeer et al. 2007; Britt et al. 2007, etc.), and therefore, we do not have much insights regarding the changes of military morale over longer periods of time in such compulsory service context. However, the specific context of the Estonian conscription service might lead to the assumption that morale is quite high in the beginning of the service, especially after soldiers finish their basic training. Drawing on research on work engagement and burnout (Sonnentag et al. 2010), we posit that there might be periods during which conscripts experience higher or lower morale. For example, conscripts probably feel quite motivated and efficient when they enter conscript service, and therefore, their engagement should be quite high and, despite the new stressful context, the possibility of burnout is not very likely due to the rather short time of military service. Further on, it could be that in the middle of the military service, the energy, motivation and enthusiasm will drop, because military life is not that exciting anymore, and, as a result, the conscripts become gradually bored. Finally, at the end of their service, the conscripts take part in the final exercise, which might mitigate the effects of burnout and boost positive emotions. This leads to our third hypothesis H3: military morale is high at the beginning, drops to its lowest level in the middle and returns to a higher level at the end of military service. 


\section{Socio-demographic variables and military morale}

There have been studies analysing correlations between work engagement/burnout and socio-demographic variables (e.g. Suzuki et al. 2015; Ahola et al. 2006). Drawing on the studies that have conceptualized military morale through work engagement and burnout (e.g. van Boxmeer et al. 2007; Ivey et al. 2015), we estimate that there may also be an association between military morale and certain socio-demographic variables. Specifically, we are interested in exploring whether socio-demographic factors, such as age, position, education, mother tongue, place of residence and university student status, affect military morale and to what extent they might predict morale.

The differences among age groups in studies on morale show that younger employees tend to experience higher levels of burnout (Patrick and Lavery 2007; Garrosa et al. 2008) and register lower levels of work engagement (James et al. 2011). In addition, Maugen and Litz (2006), using a single-item approach, found a positive correlation between age and morale; their findings have subsequently been confirmed by Whitesell and Owens (2012), as well as Farley and Veitch (2003). Consequently, we deduce that older individuals who probably have better social skills and coping mechanisms might exhibit higher morale as well.

Second, some studies have found that work status (i.e. temporary versus permanent positions) has a significant impact on burnout (Garrosa et al. 2008). Moreover, Schaufeli and Bakker (2004) found that managers seem to experience higher work engagement than employees (Kim et al. 2009). Maugen and Litz (2006) found a positive correlation between military rank and military morale (measured by a single-item approach). Additionally, Halverson and Bliese (1996), whose research focussed on morale during peacekeeping operations, also found differences between ranks. In the context of the EDF, although we focus only on conscription service, we expect to encounter differences in morale across different positions.

Third, studies that have analysed the role of education have also found correlations with work engagement and burnout (Sharma et al. 2017). For example, Yildiz Durak and Saritepeci (2019) found that occupational burnout increased for people with higher levels of education; similarly, Demus (2018) also studied well-being among conscripts and obtained the same results. However, a few studies have found education to have no significant effect on work engagement (Geldenhuys and Henn 2017; Mahboubi et al. 2014) or attitudes towards conscription service (Müürsoo 2018). We might interpret these differing findings as follows: conscripts with higher levels of education are usually older and may have set their path of life as more stable already and, therefore, may not be that motivated to enter mandatory conscription service.

Fourth, as regards research on military morale in the EDF, one of the previous studies by Parmak (2010) reported differences between morale/burnout and ethnic background among conscripts, indicating that conscripts with mother tongue other than Estonian exhibited lower levels of morale at the beginning of conscript service; however, over time, their morale showed signs of increasing morale. Moreover, Müürsoo (2018) found significant differences in attitudes towards conscription service among different language groups in EDF.

In addition to the aforementioned socio-demographic characteristics (i.e. age, service position, education and ethnicity), we decided to also include place of residence and university student status into the analyses. In this context, although we found some pieces of information in previous studies explaining, for instance, the associations between place of residence and life satisfaction as reported by Switek (2012), in general, there is little information or insufficient reliable findings on the interrelationships between military morale and these additional socio-demographic variables.

\section{Research methodology}

\section{Research sample and procedure}

The study was conducted among conscripts of the EDF. The sample was divided into three separate measurement waves over the course of 8 or 11 months to track the fluctuation of military morale over time, i.e. respondents were administered questionnaires at the start, in the middle and at the end of conscription service.

Estonian conscription service (https://mil.ee/en/ defence-forces/compulsory-military-service/), which is compulsory for all male citizens, has two tracks: service lasting approximately 11 months for leaders and specialists; and lasting approximately 8 months for soldiers in general. Training for both tracks takes place in different training centres (equivalent of battalions), except reserve officer training, which is carried out separately. Altogether, conscripts from eight training centres, divided into 29 companies (a company was, at that time, the principal unit that organized the training), participated in the study. The selection of companies was completely 
random; therefore, the authors assume no systematic bias of the results due to the unit membership.

The first wave, namely the start of conscript service, comprised 359 conscripts, while the second wave in the middle stage of military service comprised 1,354 conscripts and the last wave at the end of military service comprised 1,236 conscripts from the different training units. More precise data of socio-demographic characteristics are presented in Table 1.

Tab. 1: Socio-demographic characteristics of research samples

\begin{tabular}{|c|c|c|c|}
\hline Variable & $\begin{array}{c}\text { Wave } 1 \\
(n=359)\end{array}$ & $\begin{array}{c}\text { Wave } 2 \\
(n=1,354)\end{array}$ & $\begin{array}{c}\text { Wave } 3 \\
(n=1,236)\end{array}$ \\
\hline \multicolumn{4}{|l|}{ Gender } \\
\hline Female & 4 & 14 & 14 \\
\hline Male & 355 & 1,327 & 1,115 \\
\hline \multicolumn{4}{|l|}{ Language } \\
\hline Estonian & 329 & 1,212 & 1,018 \\
\hline Russian & 27 & 128 & 95 \\
\hline Others & - & 8 & 8 \\
\hline Missing & 3 & 6 & 115 \\
\hline \multicolumn{4}{|l|}{ Education } \\
\hline Basic & 2 & 159 & 135 \\
\hline Secondary & 255 & 1,002 & 853 \\
\hline Higher & 57 & 162 & 130 \\
\hline Missing & 45 & 31 & 118 \\
\hline \multicolumn{4}{|l|}{ Place of residence } \\
\hline Countryside & 149 & 519 & 466 \\
\hline Small town & 90 & 299 & 247 \\
\hline Major town & 118 & 511 & 417 \\
\hline Missing & 2 & 25 & 106 \\
\hline \multicolumn{4}{|l|}{ Age } \\
\hline Mean & 21.37 & 21.53 & 21.62 \\
\hline $\mathrm{SD}$ & 1.56 & 1.57 & 1.59 \\
\hline Minimum & 18 & 18 & 18 \\
\hline Maximum & 27 & 27 & 28 \\
\hline Missing & 1 & 11 & 110 \\
\hline \multicolumn{4}{|l|}{ Training unit ${ }^{1}$} \\
\hline Unit 1 & 238 & 498 & 429 \\
\hline Unit 2 & 8 & 211 & 177 \\
\hline Unit 3 & 4 & 97 & 88 \\
\hline Unit 4 & 88 & 154 & 181 \\
\hline Unit 5 & - & 145 & 155 \\
\hline Unit 6 & - & 77 & 92 \\
\hline Unit 7 & - & 62 & 111 \\
\hline Unit 8 & - & 74 & - \\
\hline Missing & 21 & 36 & 3 \\
\hline \multicolumn{4}{|l|}{ Position } \\
\hline Soldiers & 359 & 1,133 & 987 \\
\hline NCOs & - & 199 & 183 \\
\hline Reserve officers & - & 22 & 66 \\
\hline \multicolumn{4}{|l|}{ Student } \\
\hline Yes & 58 & 409 & 230 \\
\hline No & 127 & 824 & 500 \\
\hline Missing & 174 & 121 & 506 \\
\hline
\end{tabular}

Note: ${ }^{1}$ Training units are not specified by name.

SD, standard deviation; NCO, non-commissioned officer.
All questionnaires were administered to voluntary participants who filled them out in a classroom using the paper-and-pencil approach. After providing informed consent, participants were asked to fill out the questionnaires. The procedure of administering the questionnaires in three separate waves follows the logic of the EDF's conscription service, i.e. the first wave of questionnaires was administered at the end of the 3-month basic course, while the second was administered in the middle stage of conscript service and the third was administered at the end of conscription (i.e. before, during and after the final field exercise).

\section{Measures of military morale, personality and socio-democratic background}

In this study, military morale was measured by three direct morale (DMorale) items that were formulated as statements reflecting the respondent's personal perception regarding both their own level of morale (IND) and the collective morale of their unit (COL) (see e.g. Gal 1986; Gal and Manning 1987; van Boxmeer et al. 2007). These direct morale items were as follows: (1) "My personal morale is..."; (2) "the morale of my unit is..."; (3) "the morale of my fellow soldiers is...". Although several previous studies have used a similar single-item approach (e.g. Whitesell and Owens 2012; Gal 1986; Gal and Manning 1987; Dyches et al. 2017), we decided to use those variables separately as a construct of individual and collective types of morale and, additionally, aggregate all items together as one cumulative variable of direct military morale. The questionnaire used a five-point Likert scale from "strongly disagree (1)" to "strongly agree (5)". Our previous study demonstrated the following confirmatory factor analysis (CFA) figures: $\chi^{2}(5)=31.45 ; p=0.000$; root mean square error of approximation (RMSEA): 0.089; comparative fit index (CFI): 0.99; non-normed fit index (NNFI): 0.97; and standardized root mean square (SRMS): 0.035 (Kasemaa and Säälik 2021).

The Short Personality Questionnaire (SPQ-40) was used (Parmak et al. 2021), which is a 40-item instrument measuring the Big Five personality traits (Costa and McCrae 1995): Ext, Agr, Neu, Openness and Con (eight items per trait). The CFA (method of estimation: diagonally weighted least squares) demonstrated a good fit to the data for this instrument: $\chi^{2}(730)=1,545.16 ; p=0.000$; RMSEA: 0.056; CFI: 0.95; NNFI: 0.94; and SRMS: 0.086 . The questionnaire used a five-point Likert scale from "strongly disagree (1)" to "strongly agree (5)", and the respondents were asked to rate to what extent the statements applied to them. 
The socio-demographic variables included education level (basic, secondary and higher), age, gender (male or female), service position (soldier, noncommissioned officer [NCO] and reserve officer candidate), mother tongue (Estonian, Russian and others), university student status (yes or no), place of residence (i.e. where they had lived most of their lives), the name of the training centre (battalion) and their company/unit. In subsequent analyses, all variables except age were used as categorical.

\section{Main findings}

\section{Descriptive statistics and correlations}

Descriptive statistics and correlations between the variables included in the study are presented in Table 2 . Taking into account the recommended cutoff point of 0.70 (Cronbach's $\alpha$ ) for the reliability of the measurement scale (Furr and Bacharach 2014: 111), we concluded that almost all the studied variables were above the acceptable cutoff value, whereas the reliability coefficient for the summarized morale was $0.67(\alpha<0.7)$. This might be due to the research settings, because at the time of taking part in the study, the respondents had not undergone joint training and, therefore, items related to collective morale might have been perceived differently.

The results indicated that at the start of conscription service (Time 1), the Big Five personality traits exhibit a weak, but statistically significant, correlation (Spearman's rho, $\rho$ ) with individual morale, while only Ext and Agr demonstrated a statistically significant correlation with collective morale. At the start of military service, Con demonstrated statistically significant positive correlation with all morale measurements, except collective morale (Time 1), whereas Ext exhibited statistically significant positive correlation with all morale measurements, except individual morale, at the end of service (Time 3). Surprisingly, a person's Ope did not exhibit a statistically significantly correlation with morale, with the exception of individual morale, in Time 1. Moreover, Agr showed a statistically significant correlation to morale only in Time 1.

At Time 1, the other Big Five personality traits, such as Ope, Con and Neu, showed lower correlations with collective morale ( $\rho$ in the range of -0.09 and 0.15 ) and higher correlations with individual morale ( $\rho$ in the range of -0.33 and 0.35 ). The correlation difference was verified using the calculator for statistical comparison of correlations, developed by Diedenhofen and Musch (2015).

When comparing correlations of Ext and Agr with individual or collective morale, the results did not show

Tab. 2: Means, standard deviations and correlations (Spearman's $\rho$ ) of the Big Five personality traits and military morale at three different time points

\begin{tabular}{|c|c|c|c|c|c|c|c|c|c|c|}
\hline Variable & $m$ & SD & 1 & 2 & 3 & 4 & 5 & 6 & 7 & 8 \\
\hline \multicolumn{11}{|l|}{ Time $1(n=347)$} \\
\hline 1. Openness & 3.41 & 0.48 & $(0.75)$ & & & & & & & \\
\hline 2. Conscientiousness & 3.12 & 0.47 & $0.13^{*}$ & $(0.77)$ & & & & & & \\
\hline 3. Extraversion & 3.15 & 0.64 & $0.31^{\star *}$ & 0.03 & $(0.88)$ & & & & & \\
\hline 4. Agreeableness & 3.66 & 0.41 & $0.25^{\star \star}$ & $0.29^{\star \star}$ & $0.14^{\star \star}$ & $(0.80)$ & & & & \\
\hline 5. Neuroticism & 2.19 & 0.57 & $-0.21 * \star$ & $-0.32^{\star \star}$ & $-0.17^{\star \star}$ & $-0.30 * \star$ & $(0.87)$ & & & \\
\hline 6. DMorale ${ }^{1}(\mathrm{SUM})^{2}$ & 3.37 & 0.64 & 0.01 & $0.17^{\star \star}$ & $0.17^{\star \star}$ & $0.18^{\star \star}$ & $-0.22^{\star \star}$ & $(0.67)$ & & \\
\hline 7. DMorale (individual) ${ }^{3}$ & 3.56 & 0.79 & $0.14^{\star \star}$ & $0.35^{\star *}$ & $0.21^{\star *}$ & $0.16^{\star *}$ & $-0.33^{\star \star}$ & $0.64^{\star \star}$ & $(-)$ & \\
\hline 8. DMorale (collective) & 3.27 & 0.77 & -0.04 & 0.04 & $0.11^{\star}$ & $0.15^{\star *}$ & -0.09 & $0.91^{\star *}$ & $0.29 * *$ & $(0.81)$ \\
\hline \multicolumn{11}{|l|}{ Time $2(n=1,298)^{5}$} \\
\hline 6. DMorale $(S U M)^{4}$ & 3.11 & 0.83 & -0.01 & $0.19^{\star \star}$ & $0.23^{\star \star}$ & 0.07 & $-0.16^{\star}$ & $(0.85)$ & & \\
\hline 7. DMorale (individual) ${ }^{3}$ & 3.23 & 1.04 & 0.02 & $0.20^{\star \star}$ & $0.15^{\star}$ & 0.06 & -0.14 & $0.74^{\star \star}$ & $(-)$ & \\
\hline 8. DMorale (collective) & 3.08 & 0.87 & -0.02 & $0.16^{\star}$ & $0.24^{\star \star}$ & 0.08 & $-0.14^{\star}$ & $0.96^{\star \star}$ & $0.54^{\star \star}$ & $(0.83)$ \\
\hline \multicolumn{11}{|l|}{ Time $3(n=1,044)^{6}$} \\
\hline 6. DMorale $(S U M)^{4}$ & 3.32 & 0.86 & 0.05 & $0.21^{\star \star}$ & $0.19^{*}$ & 0.15 & -0.12 & $(0.82)$ & & \\
\hline 7. DMorale (individual) ${ }^{3}$ & 3.48 & 1.02 & -0.01 & $0.26^{\star \star}$ & 0.15 & 0.12 & -0.08 & $0.77^{\star \star}$ & $(-)$ & \\
\hline 8. DMorale (collective) & 3.29 & 0.90 & 0.07 & $0.18^{\star}$ & $0.18^{\star}$ & 0.14 & -0.12 & $0.97^{\star *}$ & $0.61^{* *}$ & $(0.81)$ \\
\hline
\end{tabular}

Note: ${ }^{1}$ direct morale, statements reflecting the respondent's personal perception of their own level of morale and the collective morale of their unit; ${ }^{2}$ Two collective- and one individual-level items; ${ }^{3}$ this variable consists of one item; ${ }^{4}$ three collective-level morale items and one individual-level item; Cronbach's $\alpha$ values are in parentheses; correlations in boxes have been calculated from different sample sizes, ${ }^{5}$ Time $2(n=190)$ and ${ }^{6}$ Time $3(n=171)$.

${ }^{*} p<0.05 ;{ }^{* \star} p<0.01$. 
any significant difference, which may indicate that collective morale is probably influenced more strongly by some other elements of military life and not that much by personality-related variables. Another explanation may be that individual members do not perceive their unit's collective morale in a consistent manner, with the exception of individuals with high Agr or Ext. Agr and Con demonstrated higher correlations with morale variables at Time 3 compared to the results at Time 2 .

In order to ascertain whether the fluctuations of military morale across different measurement waves/times were statistically significant, the Cohen's effect size test was performed. In previous research, Cohen's $d /$ Hedges' $g$ (Lenhard and Lenhard 2016) has been used in the case of uneven sample sizes (Durlak 2009). The results (see Table 3) demonstrated that individual, collective and summarized types of morale were lower in the middle stage of military service (for all variables) as compared to the means at the start or at the end of the training cycle. In addition, an intermediate decreasing effect was observed in the case of individual morale-related variables (this interpretation follows the recommendations provided by Sawilowsky [2009]) between Time 1 and Time 2 (Cohen's $d:-0.333)$ and a small effect was seen in the case of collective morale (Cohen's $d:-0.176)$. At the same time, between Time 2 and Time 3, both individual and collective types of morale increased by a small, yet statistically significant, effect (Cohen's $d$ between 0.259 and 0.234). According to the Common Language Effect Size (Lakens 2013), the chance that, for a randomly selected pair of individuals, the evaluated morale at Time 1 is higher than the same at Time 2 is between 55\% and 59\%, whereas for Time 2 and Time 3, it is approximately $57 \%$, and for Time 1 and Time 3, it is between $50 \%$ and $52 \%$; this result generally supports the results of Cohen's $d$.

\section{Effects of socio-demographic characteristics on military morale}

A series of binary logistic regression analyses was conducted to assess the impact of personality and sociodemographic variables on individual and collective types of morale (i.e. morale was divided between two categories by the middle scale point). Logistic regression was used because it allows analysis of the impact of the ordinal and nominal variables on the dependant variable (Field 2013: 761), however, the sample size (number of cases per subgroup) demanded the use of its simplest version; thus, binary logistic regression was chosen for the analyses. Based on the results of analyses of variance (ANOVAs), we included personality traits (Time 1) together with age, education, position, status of student and place of residence into the analyses (times 1, 2 and 3). Despite the ANOVA results demonstrating the importance of training unit on the military morale, we did not include this variable into subsequent analyses. Separate models were built to explain individual and collective types of morale at all three time points of measurement. The models with only statistically significant predictors for either individual or collective morale are presented.

The base model (only with the constant), which anticipated the individual morale in Time 1, predicted correctly $58 \%$ of cases into clusters of either low or high morale. However, when including personality traits, the model predicted correctly $68.8 \%$ of cases, which indicated significant improvement $\left(\Delta \chi^{2}(5)=54.049, p=0.000, p<0.05\right)$. Thus, Con, Ext and Neu demonstrated statistically significant contribution to individual military morale at Time 1 (Table 4), and altogether, the model explained between $12 \%$ and $22 \%$ of the variance in low and high individual morale.

Tab. 3: Cohen's $d$ values used to compare the mean differences

\begin{tabular}{|c|c|c|c|c|}
\hline Variable & Mean difference & $d / g$ & $\mathrm{Cl}$ & CLES \\
\hline 1. DMorale ${ }^{1}(\text { IND) })^{2}$ : Time $1 \rightarrow$ Time 2 & -0.33 & -0.333 & {$[-0.449,-0.216]$} & 0.593 \\
\hline 2. DMorale (IND): Time1 $\rightarrow$ Time 3 & -0.08 & -0.082 & {$[-0.199,0.035]$} & 0.523 \\
\hline 3. DMorale (IND): Time $2 \rightarrow$ Time 3 & 0.25 & 0.243 & {$[0.167,0.319]$} & 0.568 \\
\hline 1. DMorale $(\mathrm{COL})^{3}$ : Time $1 \rightarrow$ Time 2 & -0.15 & -0.176 & {$[-0.292,-0.059]$} & 0.549 \\
\hline 2. DMorale (COL): Time $1 \rightarrow$ Time 3 & 0.055 & 0.064 & {$[-0.053,0.181]$} & 0.518 \\
\hline 3. DMorale $(\mathrm{COL})$ : Time $2 \rightarrow$ Time 3 & 0.205 & 0.234 & {$[0.158,0.31]$} & 0.566 \\
\hline 1. DMorale (SUM): Time $1 \rightarrow$ Time 2 & -0.219 & -0.276 & {$[-0.392,-0.16]$} & 0.577 \\
\hline 2. DMorale (SUM): Time1 $\rightarrow$ Time 3 & -0.003 & -0.003 & {$[-0.12,0.114]$} & 0.501 \\
\hline 3. DMorale (SUM): Time $2 \rightarrow$ Time 3 & 0.217 & 0.259 & {$[0.183,0.336]$} & 0.573 \\
\hline
\end{tabular}

Note: Confidence interval: 95\%; $\underline{d}$ : Cohen's effect size coefficient; g: Hedges' effect size coefficient. ${ }^{1}$ direct morale, statements reflecting the respondent's personal perception of their own level of morale and the collective morale of their unit; ${ }^{2}$ respondent's personal perception regarding their own level of morale; ${ }^{3}$ respondent's personal perception the collective morale of their unit; $\mathrm{Cl}$, confidence interval; CLES, common language effect size.

However, we might also state that individual morale demonstrated higher means compared to collective morale at the three time points $(t(358)=5.82, p=0.000 ; t(1,382)=4.391, p=0.000$; and $t(1,274)=6.295, p=0.000$, respectively $)$. 
Tab. 4: The results of binary logistic regression, predicting individual and collective types of military morale (DV1) at Time 1 by personality and socio-demographic variables (IVs')

\begin{tabular}{|c|c|c|c|c|c|c|c|c|}
\hline \multirow{2}{*}{ Predictor (IV') } & \multirow{2}{*}{ B } & \multirow{2}{*}{ SE } & \multirow{2}{*}{ Wald's $\chi^{2}$} & \multirow{2}{*}{$d f$} & \multirow[b]{2}{*}{$p$} & \multirow{2}{*}{$\operatorname{Exp}(B)$} & \multicolumn{2}{|c|}{ 95\% CI for $\operatorname{Exp(B)}$} \\
\hline & & & & & & & Lower & Upper \\
\hline \multicolumn{9}{|c|}{ Time 1: Individual morale (DV'), $n=317$} \\
\hline Openness & 0.024 & 0.289 & 0.007 & 1 & 0.934 & 1.024 & 0.582 & 1.803 \\
\hline Consciousness & 1.081 & 0.294 & 13.553 & 1 & 0.000 & 2.949 & 1.658 & 5.244 \\
\hline Extraversion & 0.674 & 0.207 & 10.592 & 1 & 0.001 & 1.962 & 1.307 & 2.944 \\
\hline Agreeableness & 0.284 & 0.322 & 0.782 & 1 & 0.377 & 1.329 & 0.707 & 2.497 \\
\hline Neuroticism & -0.758 & 0.259 & 8.585 & 1 & 0.003 & 0.486 & 0.282 & 0.778 \\
\hline \multirow[t]{2}{*}{ Constant } & -4.584 & 1.890 & 5.879 & 1 & 0.015 & 0.010 & na & na \\
\hline & & & $\chi^{2}$ & $d f$ & $p$ & & & \\
\hline Likelihood ratio test & & & 54.049 & 5 & 0.000 & & & \\
\hline Hosmer and Lemeshow & & & 11.892 & 8 & 0.156 & & & \\
\hline \multicolumn{9}{|c|}{$R^{2}=0.125$ (Hosmer and Lemeshow), 0.157 (Cox and Snell), 0.211 (Nagelkerke) } \\
\hline \multicolumn{9}{|c|}{ Time 1: Collective morale (DV'), $n=281$} \\
\hline Openness & -0.582 & 0.295 & 3.885 & 1 & 0.049 & 0.559 & 0.313 & 0.997 \\
\hline Consciousness & -0.103 & 0.284 & 0.132 & 1 & 0.716 & 0.902 & 0.517 & 1.575 \\
\hline Extraversion & 0.209 & 0.202 & 1.065 & 1 & 0.302 & 1.232 & 0.829 & 1.832 \\
\hline Agreeableness & 0.781 & 0.337 & 5.363 & 1 & 0.021 & 2.183 & 1.127 & 4.226 \\
\hline Neuroticism & -0.339 & 0.261 & 1.687 & 1 & 0.194 & 0.712 & 0.427 & 1.189 \\
\hline Language & 1.231 & 0.602 & 4.187 & 1 & 0.041 & 3.426 & 1.053 & 11.144 \\
\hline Education & na & na & 6.356 & 2 & 0.042 & na & na & na \\
\hline Education (1) & 0.440 & 1.464 & 0.090 & 1 & 0.764 & 1.552 & 0.088 & 27.335 \\
\hline Education (2) & 0.430 & 1.492 & 0.083 & 1 & 0.773 & 0.651 & 0.035 & 12.107 \\
\hline \multirow[t]{2}{*}{ Constant } & -0.910 & 2.423 & 0.141 & 1 & 0.707 & 0.402 & na & na \\
\hline & & & $\chi^{2}$ & $d f$ & $p$ & & & \\
\hline \multirow{2}{*}{\multicolumn{3}{|c|}{$\begin{array}{l}\text { Likelihood ratio test } \\
\text { Hosmer and Lemeshow }\end{array}$}} & 20.442 & 8 & 0.009 & & & \\
\hline & & & 8.448 & 8 & 0.391 & & & \\
\hline \multicolumn{9}{|c|}{$R^{2}=0.053$ (Hosmer and Lemeshow), 0.070 (Cox and Snell), 0.094 (Nagelkerke) } \\
\hline
\end{tabular}

Note: Regression method: Enter; Education - basic education; education (1) = secondary education; education (2) = higher education; na - not applicable; $\operatorname{Exp}(B)$ - odds ratio. ${ }^{1}$ dependent variable; ${ }^{2}$ independent variable.

$\mathrm{Cl}$, confidence interval; df, degrees of freedom; $\mathrm{SE}$, standard error.

The model that evaluated collective morale at Time 1 (Table 4) predicted correctly 52\% of cases (only with the constant), $56.9 \%$ of cases (adding personality traits) and $63.3 \%$ of cases (adding mother tongue and the level of education) into clusters of either low or high morale. Thus, these numbers indicate slight improvement of the model due to personality $\left(\Delta \chi^{2}(5)=10.453, p=0.063\right.$, $p>0.05)$ and significant improvement due to education and mother tongue $\left(\Delta \chi^{2}(3)=9.989, p=0.019, p<0.05\right)$. Thus, the results showed statistically significant impact of Ope, Agr, mother tongue and education (especially basic education) on the collective military morale, measured at Time 1. Altogether, the model explained between 5\% and $9 \%$ of variance in low and high collective morale.

The second set of models analysed military morale at Time 2 (Table 5). The model describing individual morale predicted correctly $56.6 \%$ of cases into clusters of either low or high morale when only the constant was included in it and $57.8 \%$ of cases when the status of student, age and positions were added. Nevertheless, the model was significant $\left(\Delta \chi^{2}(4)=16.120, p=0.003, p<0.05\right)$. Thus, we concluded that the status of student, age and positions had some impact, although very small (the model explained approximately $1 \%-2 \%$ of the variance), on the individual morale in the middle stage of the conscription service. The model explained collective military morale at Time 2 (Table 5), predicted correctly $51.8 \%$ of cases of low and high morale with only constant in it and $56 \%$ of cases when the status of student, education and positions were added. Nevertheless, the model was statistically significant $\left(\Delta \chi^{2}(5)=35.604, p=0.000, p<0.05\right)$. Thus, we concluded that the status of student, age and positions had 
Tab. 5: The results of binary logistic regression, predicting individual and collective types of military morale (DV) at Time 2 by personality and socio-demographic variables (IVs)

\begin{tabular}{|c|c|c|c|c|c|c|c|c|}
\hline \multirow{2}{*}{ Predictor (IV) } & \multirow{2}{*}{ B } & \multirow{2}{*}{ SE } & \multirow{2}{*}{ Wald's $\chi^{2}$} & \multirow{2}{*}{$d f$} & \multirow{2}{*}{$p$} & \multirow{2}{*}{$\operatorname{Exp}(B)$} & \multicolumn{2}{|c|}{$95 \% \mathrm{Cl}$ for $\operatorname{Exp}(\mathrm{B})$} \\
\hline & & & & & & & Lower & Upper \\
\hline \multicolumn{9}{|c|}{ Time 2: Individual morale (DV), $n=1,227$} \\
\hline Age & -0.072 & 0.037 & 3.792 & 1 & 0.051 & 0.930 & 0.865 & 1.000 \\
\hline Position & na & na & 5.917 & 2 & 0.052 & na & na & na \\
\hline Position (1) & 0.382 & 0.159 & 5.741 & 1 & 0.017 & 1.465 & 1.072 & 2.003 \\
\hline Position (2) & -0.124 & 0.442 & 0.079 & 1 & 0.778 & 0.883 & 0.372 & 2.099 \\
\hline Status of student & 0.307 & 0.124 & 6.145 & 1 & 0.013 & 1.360 & 1.066 & 1.734 \\
\hline \multirow[t]{2}{*}{ Constant } & 1.064 & 0.809 & 1.728 & 1 & 0.189 & 2.897 & na & na \\
\hline & & & $\chi^{2}$ & $d f$ & $p$ & & & \\
\hline Likelihood ratio test & & & 16.120 & 4 & 0.003 & & & \\
\hline Hosmer and Lemeshow & & & 15.090 & 7 & 0.35 & & & \\
\hline \multicolumn{9}{|c|}{$R^{2}=0.010$ (Hosmer and Lemeshow), 0.013 (Cox and Snell), 0.017 (Nagelkerke) } \\
\hline \multicolumn{9}{|c|}{ Time 2: Collective morale (DV), $n=1,219$} \\
\hline Status of student & 0.338 & 0.128 & 6.971 & 1 & 0.008 & 1.402 & 1.091 & 1.801 \\
\hline Education & na & na & 9.459 & 2 & 0.009 & na & na & na \\
\hline Education (1) & -0.350 & 0.192 & 3.322 & 1 & 0.068 & 0.705 & 0.484 & 1.027 \\
\hline Education (2) & -0.760 & 0.249 & 9.323 & 1 & 0.002 & 0.468 & 0.287 & 0.762 \\
\hline Position & na & na & 11.598 & 2 & 0.003 & na & na & na \\
\hline Position (1) & 0.138 & 0.160 & 0.742 & 1 & 0.389 & 1.148 & 0.839 & 1.572 \\
\hline Position (2) & 2.098 & 0.630 & 11.087 & 1 & 0.001 & 8.147 & 2.370 & 28.004 \\
\hline \multirow[t]{2}{*}{ Constant } & 0.011 & 0.215 & 0.003 & 1 & 0.958 & 1.011 & na & na \\
\hline & & & $\chi^{2}$ & $d f$ & $p$ & & & \\
\hline Likelihood ratio test & & & 35.604 & 5 & 0.000 & & & \\
\hline Hosmer and Lemeshow & & & 0.799 & 4 & 0.939 & & & \\
\hline \multicolumn{9}{|c|}{$R^{2}=0.022($ Hosmer and Lemeshow), 0.029 (Cox and Snell) 0.038 (Nagelkerke) } \\
\hline
\end{tabular}

Note: Regression method: Enter; Position - soldiers; position (1) - non-commissioned officers; position (2) - reserve officers; education - basic education; education (1) - secondary education; education (2) - higher education; na - not applicable; $\operatorname{Exp}(B)$ - odds ratio.

$\mathrm{Cl}$, confidence interval; $\mathrm{df}$, degrees of freedom; SE, standard error; DV dependent variable; IV independent variable.

some impact, although very small (the model explained approximately $2 \%-4 \%$ of the variance), on the collective morale at the middle of the conscription service.

Lastly, we analysed the descriptive power of sociodemographic variables with regard to individual and collective types of morale at Time 3 (Table 6). Firstly, individual morale (DV) was analysed. The model including only the constant predicted correctly $55.1 \%$ of cases for low and high morale, and it did not change when adding position as the only significant predictor to the model. Thus, it indicated no improvement in terms of the predictive power of the model. Nevertheless, the model itself was statistically significant $(\Delta \chi 2(2)=8.580, p=0.014, p<0.05)$. Thus, we concluded that the position of the conscripts had an impact, although very small (the model explained approximately $1 \%$ of the variance), on the individual morale at the end of the conscription service.
Finally, the model of the collective military morale at the end of the service (Time 3) predicted $56.1 \%$ of cases properly (with only constant) and $56.8 \%$ of cases into clusters of either low or high morale, when the education and place of residence were added as significant predictors. It indicated very little improvement in terms of the descriptive power of the model; nevertheless, the model was statistically significant $\left(\Delta \chi^{2}(6)=15.870, p=0.014, p<0.05\right)$ and it explained approximately $1 \%-2 \%$ of variance of low and high morale.

\section{Discussion}

This study examined the perceptions of individual and collective types of military morale among conscripts of the EDF and sought to ascertain how these different types 
Tab. 6: The results of binary logistic regression, predicting individual and collective types of military morale (DV) at Time 3 by personality and socio-demographic variables (IVs)

\begin{tabular}{|c|c|c|c|c|c|c|c|c|}
\hline \multirow{2}{*}{ Predictor (IV) } & \multirow{2}{*}{ B } & \multirow{2}{*}{ SE } & \multirow{2}{*}{ Wald's $\chi^{2}$} & \multirow{2}{*}{$d f$} & \multirow{2}{*}{$p$} & \multirow{2}{*}{$\operatorname{Exp}(B)$} & \multicolumn{2}{|c|}{$95 \% \mathrm{Cl}$ for $\operatorname{Exp}(\mathrm{B})$} \\
\hline & & & & & & & Lower & Upper \\
\hline & \multicolumn{8}{|c|}{ Time 3: Individual morale (DV), $n=1,236$} \\
\hline Position & na & na & 8.356 & 2 & 0.015 & na & na & na \\
\hline Position (1) & 0.355 & 0.165 & 4.636 & 1 & 0.031 & 1.426 & 1.032 & 1.971 \\
\hline Position (2) & 0.569 & 0.269 & 4.487 & 1 & 0.034 & 1.767 & 1.043 & 2.993 \\
\hline \multirow[t]{2}{*}{ Constant } & 0.124 & 0.064 & 3.765 & 1 & 0.052 & 1.132 & na & na \\
\hline & & & $\chi^{2}$ & $d f$ & $p$ & & & \\
\hline Likelihood ratio test & & & 8.580 & 2 & 0.014 & & & \\
\hline Hosmer and Lemeshow & & & 0.000 & 1 & 1.000 & & & \\
\hline \multicolumn{9}{|c|}{$R^{2}=0.005$ (Hosmer and Lemeshow), 0.007 (Cox and Snell), 0.009 (Nagelkerke) } \\
\hline & \multicolumn{8}{|c|}{ Time 3: Collective morale (DV), $n=1,113$} \\
\hline Education & na & na & 5.328 & 2 & 0.070 & na & na & na \\
\hline Education (1) & -0.284 & 0.194 & 2.141 & 1 & 0.143 & 0.753 & 0.515 & 1.101 \\
\hline Education (2) & -0.583 & 0.253 & 5.318 & 1 & 0.021 & 0.558 & 0.340 & 0.916 \\
\hline Place of residence & na & na & 9.788 & 4 & 0.044 & na & na & na \\
\hline Place of residence (1) & -0.275 & 0.198 & 1.934 & 1 & 0.164 & 0.760 & 0.516 & 1.119 \\
\hline Place of residence (2) & -0.345 & 0.197 & 3.073 & 1 & 0.080 & 0.708 & 0.481 & 1.042 \\
\hline Place of residence (3) & -0.213 & 0.278 & 0.588 & 1 & 0.443 & 0.808 & 0.468 & 1.394 \\
\hline Place of residence (4) & -0.493 & 0.160 & 9.541 & 1 & 0.002 & 0.611 & 0.447 & 0.835 \\
\hline \multirow[t]{2}{*}{ Constant } & 0.853 & 0.213 & 16.042 & 1 & 0.000 & 2.346 & na & na \\
\hline & & & $\chi^{2}$ & $d f$ & $p$ & & & \\
\hline Likelihood ratio test & & & 15.870 & 6 & 0.014 & & & \\
\hline \multicolumn{3}{|l|}{ Hosmer and Lemeshow } & 1.233 & 5 & 0.942 & & & \\
\hline \multicolumn{9}{|c|}{$R^{2}=0.010$ (Hosmer and Lemeshow), 0.014 (Cox and Snell), 0.019 (Nagelkerke) } \\
\hline
\end{tabular}

Note: Regression method: Enter; Position - soldiers; position (1) - non-commissioned officers; position (2) - reserve officers;

education - basic education; education (1) - secondary education; education (2) - higher education; place of residence - countryside; place of residence (1) - borough; place of residence (2) - small town; place of residence (3) - county centre; place of residence (4) - bigger town; na - not applicable; $\operatorname{Exp}(B)$ - odds ratio.

$\mathrm{Cl}$, confidence interval; df, degrees of freedom; SE, standard error; DV dependent variable; IV independent variable.

of morale are affected by individual characteristics, such as the Big Five personality traits or socio-demographic variables. The interrelationships (especially with personality traits) established in the course of our research draw on the assumption that personality affects individual interpretations of and reactions to the environment, as has been suggested by several other authors (McCrae and Costa 2008: 162-163; Higgins and Scholer 2008: 184; Mischel and Shoda 2008: 209). In addition, the cognitive-affective theory of personality developed by Mischel and Shoda (2008) also posits that personality may influence how individuals encode and evaluate information coming from their environment.

Our hypotheses predicted that military morale is positively correlated with the following Big Five personality traits: Con, Ext, Agr and Ope (H1.1) and negatively correlated with $\mathrm{Neu}$ (H1.2). These hypotheses were confirmed partially, i.e. the predicted relationships were confirmed only for the first stage of conscript service, when all personality traits exhibited statistically significant relationships with the perception of individual morale. However, across all Big Five traits, only Con demonstrated significant correlation with individual morale throughout the whole conscription period, supported by Ext up to the middle stage of military service. On the other hand, the hypotheses posited with regard to collective morale yielded only low correlations, that too only with Ext and Agr (Time 1). During the middle stage of conscript service, both individual and collective types of morale showed significant correlations with Con and Ext, whereas Neu demonstrated correlation only with the collective morale. Con and Ext maintained their significant correlation with collective morale until the end of military service. Overall, this pattern of interrelationships was also supported by 
the results of logistic regression analysis, which demonstrated that personality traits such as Con, Ext and Neu predict individual morale statistically significantly in the beginning of the service, whereas only Agr seemed to bear an effect on collective morale.

Conscientious people, dutiful and self-disciplined (McCrae and Costa 2008), tend to rate their individual morale as very high. However, because conscript service is mandatory in Estonia, there are probably people whose self-discipline is actually lower and who are not that dutiful, which might explain why Conscientious people rated their own morale higher than that of their unit members. Surprisingly, Extraverted people's sense of enthusiasm and energy (Costa and McCrae 1992) to engage in unit activities seemed to change over time, from being more closely related to individual morale in the beginning to demonstrating a stronger correlation with collective morale in the middle stage and at the end of service. At the same time, conscripts who tend to experience anxiety, depression and other negative emotions (McCrae and Costa 2008) seemed to rate their individual morale less highly, especially at the beginning of military service. Perhaps, this could be explained by the fact that either conscripts are more prone to experiencing the negative aspects of military service primarily at the start and not so much at the end of their service or there are coping mechanisms that conscripts might have developed during the course of military training.

Another hypothesis - Agr and Ext are more strongly correlated with collective rather than individual morale (H2.1) - was confirmed by the absolute values of the correlations at different time points. However, Agr did not show any differences in correlations with either individual or collective morale and, thus, Agr does not support our hypothesis. Nevertheless, this is an interesting result, demonstrating that people with high Agr and, therefore, better suited for teamwork and cooperation (McCrae and Costa 2008), did not register a high level of collective morale. This result could be explained by the fact that the nature of military service does not support cooperation as such, and as a result, the potential positive effect is not amplified by the quality of the aspects that people with high Agr might value. On the other hand, Ext demonstrated mixed results: in the beginning of conscript service, Ext was more strongly correlated with individual morale than with collective morale, whereas in the middle stage of military service, the correlation was reversed. This could be explained by the fact that unit-level training is not in focus until the middle of service, and therefore Ext - as a coping mechanism - tends to support the feeling of individual morale and not collective morale. However, the results indicate that this tendency changes during the course of service. For example, in the middle stage of military service, Ext tends to support primarily collective, and not individual, morale.

Hypothesis H2.2 - Con and Neu are more strongly correlated with individual than collective morale - was proven in the case of Con throughout the whole service cycle, whereas Neu showed a stronger correlation with individual morale only at the beginning of military service. The latter might be explained by the change of focus to more unit-based activities during the course of the training cycle, as already mentioned before.

The hypothesis about military morale fluctuation over time was drawn from previous research on small-unit cohesion by Vaitkus and Griffith (1990) and Siebold (1999, 2006), as well as from research on work engagement and burnout by Sonnentag et al. (2010). This hypothesis was confirmed, and the change was found to be statistically significant. Thus, we can say that over the course of compulsory military service, conscripts' individual morale as well as that of the unit was affected. For example, in the beginning of service, right after completing the basic course, the feeling of enthusiasm and persistence registered was quite high, but then reduced drastically. Previously, the EDF's annual conscript survey found that the middle stage of conscript service is often perceived as 'a long and boring, a tedious and pointless period' (e.g. Demus 2018). In the EDF, compulsory military service ends with a final practical exercise, which is believed to provide a renewed opportunity to experience something close to a real military situation, eliciting excitement, as well as an increased sense of cohesion and camaraderie within the unit.

The effect of socio-demographic factors (e.g. age, position, education, mother tongue, place of residence and status of university student) on military morale, as well as their predictive capacity, was analysed by binary logistic regression. Generally, socio-demographic variables did not seem to play a significant role in explaining the variance of either individual or collective military morale. Altogether, university student status, the level of education, age, position and place of residence were shown to be statistically significant for both individual and collective types of morale; however, the effect sizes were quite small $(1 \%-2 \%$ for individual and $2 \%-4 \%$ for collective morale), demonstrating that an individual's perception of morale is not dependent on those variables. In order to show the similarity of these results with those from previous research, we refer to the concept of work 
engagement and burnout (Maslach and Leiter 1997) as an analogue, because morale has sometimes been explained using the components of these two factors (van Boxmeer et al. 2007; Kasemaa and Säälik 2021). For example, Haley et al. (2013) found that age may have a positive correlation with morale, whereas Aguayo et al. (2017), in their study of police officers, did not find age or sex to have any significant impact on burnout. Additionally, Akhtar et al. (2015) found that age is a statistically significant predictor of work engagement. Overall, there were no other equivalent reliable research results available on the issue of socio-demographic characteristics explaining the level of morale that could be compared to the findings of this study.

\section{Conclusion}

The quest to ascertain the factors that contribute to individual or collective performance (i.e. the factors that explain the secrets of group success, on the one hand, and those that mitigate the devastating effects of burnout, on the other hand) has led to the understanding that there are several interrelated psychological and organizational phenomena that describe and explain such processes, for example high level of morale contributes to success and satisfaction, while the opposite (i.e. low level of morale) has a detrimental effect.

This study focussed on the interrelationships among morale, the Big Five personality traits and sociodemographic factors in the military context. The research was carried out through measurement of direct morale and by administering the Big Five personality questionnaire. The results indicate that, in the context of military conscription, personality traits appear to correlate with, and may even predict, the level of perceived individual or collective morale. Of the Big Five personality traits, conscientiousness and extraversion, and to some extent also neuroticism, were shown to exhibit a more persistent relationship to the conscripts' perception of both individual and collective types of morale.

In addition, this longitudinal study also helped to highlight the fluctuating nature of military morale across the different stages of the conscription service cycle, i.e. the perceptions of morale are the highest at the start of military service, drop in the middle, and rise back up at the end of the service period. Furthermore, it seems that socio-demographic factors have a relatively modest effect on the conscripts' perception of their individual morale or the collective morale of their unit.

\section{Biography}

Antek Kasemaa received his Master of Arts (MA) degree in Organizational Behaviour in 2008 from the Tallinn University, Estonia. He is a former Lecturer of leadership at the Estonian Military Academy and current lecturer of leadership and organisational theory at the Tallinn University. His research interests are motivation to lead, small unit cohesion, military morale, leadership and organizational culture.

Ülle Säälik is Lecturer of Pedagogy, Educational Psychology and Research Methods at the Estonian Military Academy. She has obtained Doctor of Philosophy $(\mathrm{PhD})$ degree in Educational Sciences. Her main research areas are the different aspects of educational psychology, morale, identity and multilingualism.

\section{References}

Aguayo, R., Vargas, C., Cañadas, G. R., \& De la Fuente, E. I. (2017). Are socio-demographic factors associated to burnout syndrome in police officers? A correlational meta-analysis. Anales de Psicología, 33(2), pp. 383-392. doi: 10.6018/ analesps.33.2.260391.

Ahola, K., Honkonen, T., Isometsä, E., Kalimo, R., Nykyri, E., Koskinen, S., et al. (2006). Burnout in the general population. Social Psychiatry and Psychiatric Epidemiology, 41, p. 11. doi: 10.1007/s00127-005-0011-5.

Akhtar, R., Boustani, L., Tsivrikos, D., \& Chamorro-Premuzic, T. (2015). The engageable personality: Personality and trait El as predictors of work engagement. Personality and Individual Differences, 73, pp. 44-49.

Allport, G. W. (1961). Pattern and Growth in Personality. Holt, Rinehart \& Winston, New York.

Bakker, A. B., Demerouti, E., \& ten Brummelhuis, L. L. (2012). Work engagement, performance, and active learning: The role of conscientiousness. Journal of Vocational Behavior, 80(2), pp. 555-564.

Bakker, A. B., van der Zee, K. I., Lewig, K. A., \& Dollard, M. F. (2002). The relationship between the Big Five personality factors and burnout: A study among volunteer counselors. The Journal of Social Psychology, 135(5), pp. 1-19.

Bartone, P. T., \& Adler, A. B. (1999). Cohesion over time in a peacekeeping medical task force. Military Psychology, 11(1), pp. 85-107.

Berry, C. M., Ones, D. S., \& Sackett, P. R. (2007). Interpersonal deviance, organizational deviance, and their common correlates: A review and meta-analysis. Journal of Applied Psychology, 92(2), pp. 410-424.

Britt, T. W., Adler, A. B., Bliese, P. D., \& Moore, D.-W. (2013). Morale as a moderator of the combat exposure-PTSD symptom relationship. Journal of Traumatic Stress, 26, pp. 1-8.

Britt, T. W., \& Dickinson, J. M. (2006). Morale during military operations: A positive psychology approach. In Britt, T. W., 
Castro, C. A., \& Adler, A. B. (eds.), Military Life:

The Psychology of Serving in Peace and Combat. Volume 1: Military Performance, Praeger Security International, Westport, CT, pp. 157-184.

Britt, T. W., Dickinson, J. M., Moore, D., Castro, C. A., \& Adler, A. B. (2007). Correlates and consequences of morale versus depression under stressful conditions. Journal of Occupational Health Psychology, 12(1), pp. 34-47.

Britt, T. W., \& Oliver, K. (2013). Morale and cohesion as contributors to resilience. In Sinclair R. R., \& Britt, T. W. (eds.), Building Resilience in Military Personnel: Theory and Practice. American Psychological Association, Washington, DC, pp. 47-65.

Bühler, K. E., \& Land, T. (2003). Burnout and personality in intensive care: An empirical study. Hospital Topics, 81(4), pp. 5-12.

Chambel, M. J., Castanheira, F., Oliveira-Cruz, F., \& Lopes, S. (2015). Work context support and Portuguese soldiers' well-being: The mediating role of autonomous motivation. Military Psychology, 27(5), pp. 297-310.

Chen, G., \& Bliese, P. D. (2002). The role of different levels of leadership in predicting self- and collective efficacy: Evidence for discontinuity. Journal of Applied Psychology, 87(3), pp. 549-556. doi: 10.1037/0021-9010.87.3.549.

Chiaburu, D. S., Oh, I.-S., Berry, C. M., Li, N., \& Gardner, R. G. (2011). The five-factor model of personality traits and organizational citizenship behaviors: A meta-analysis. Journal of Applied Psychology, 96(6), pp. 1140-1166.

Child, I. L. (1968). Personality in culture. In Borgatta, E. F., \& Lambert, W. W. (eds.), Handbook of Personality Theory and Research. Rand McNally, Chicago, pp. 82-148.

Costa, P. T., \& McCrae, R. R. (1995). Domains and facets: Hierarchical personality assessment using the revised NEO personality inventory. Journal of Personality Assessment, 64(1), pp. 21-50.

Costa, P. T. Jr., \& McCrae, R. R. (1992). Four ways five factors are basic. Personality and Individual Differences, 13(6), pp. 653-665.

Cotton, P., \& Hart, P. M. (2003). Occupational well-being and performance: A review of organizational health research. Australian Psychologist, 28(2), pp. 118-127.

Cremers, M. (2018). Morale of Dutch units deployed in the period 2014-2017. Unpublished presentation in Annual International Military Testing Association Conference in Kingston, Canada 15th-19th of Oct 2018.

Dalal, R. S. (2005). A meta-analysis of the relationship between organizational citizenship behavior and counterproductive work behavior. Journal of Applied Psychology, 90(6), pp. 1241-1255.

Demus, E. (2018). Rahulolu ajateenistusega ja seda mõjutavad tegurid Eesti Kaitseväes [Satisfaction with compulsory military service in the Estonian defense forces and determining factors]. Estonian Journal of Military Studies, 6, pp. 108-137.

Diedenhofen, B., \& Musch, J. (2015). cocor: A comprehensive solution for the statistical comparison of correlations. PLOS ONE, 10(4), p. e0121945. doi: 10.1371/journal.pone.0121945.

Durlak, J. A. (2009). How to select, calculate, and interpret effect sizes. Journal of Pediatric Psychology, 34(9), pp. 917-928, doi: 10.1093/jpepsy/jsp004.

Dyches, K. D., Saboe, K. N., Anderson, J. A., Wilk, J. E., Hinman, S. J., Sipos, M. L., et al. (2017). Modeling the indirect association of combat exposure with anger and aggression during combat deployment: The moderating role of perceived unit morale. Military Psychology, 29(4), pp. 260-270.

Erdheim, J., Wang, M., \& Zickar, M. J. (2006). Linking the Big Five personality constructs to organizational commitment. Personality and Individual Differences, 41(5), pp. 959-970.

Euwema, M., van Boxmeer, F., Broesder, W., OpdenBuijs, T., Verwijs, C., \& Vogelaar, A. (2009). The morale of the peacekeeping warrior. Unpublished presentation in Annual International Military Testing Association Conference in Tartu, Estonia, 2-5 Nov, 2009.

Farley, K. M. J., \& Veitch, J. A. (2003). Measuring morale, cohesion and confidence in leadership: What are the implication for leaders? Canadian Journal of Police and Security Services, 1(4), pp. 353-364.

Fennell, J. (2014). Morale and combat performance: An introduction. Journal of Strategic Studies, 37(6-7), pp. 796-798.

Field, A. (2013). Discovering statistics using IMB SPSS statistics. Sage, Los Angeles, US: Thousand Oaks.

Funder, D. C. (2001). Personality. Annual Review of Psychology, 52, pp. 197-221.

Furr, R. M., \& Bacharach, V. R. (2014). Psychometrics: An Introduction, 2nd edn. Sage, Thousand Oaks, CA, US.

Gal, R. (1986). Unit morale: From a theoretical puzzle to an empirical illustration - An Israeli example. Journal of Applied Social Psychology, 16(6), pp. 549-564.

Gal, R., \& Manning, F. J. (1987). Morale and its components: A cross-national comparison. Journal of Applied Social Psychology, 17(4), pp. 369-391.

Garrosa, E., Moreno-Jiménez, B., Liang, Y., \& González, J.L. (2008). The relationship between socio-demographic variables, job stressors, Burnout, and Hardy personality in nurses: An exploratory study. International Journal of Nursing Studies, 45, pp. 418-427. doi: 10.1016/j.ijnurstu.2006.09.003.

Geldenhuys, M., \& Henn, C. M. (2017). The relationship between demographic variables and well-being of women in South African workplaces. South African Journal of Human Resource Management. Gale Academic OneFile (accessed March 4, 2020).

Griffith, J. (1988). Measurement of group cohesion in U.S. army units. Basic and Applied Social Psychology, 9(2), pp. 149-171.

Gustafsson, G., Persson, B., Eriksson, S., Norberg, A., \& Strandberg, G. (2009). Personality traits among burnt out and non-burnt out health-care personnel at the same workplaces: A pilot study. International Journal of Mental Health Nursing, 18(5), pp. 336-348.

Haley, L.-M., Mostert, K., \& Els, C. (2013). Burnout and work engagement for different age groups: Examining group-level differences and predictors. Journal of Psychology in Africa, 23(2), pp. 283-295 Available at: https://www. researchgate.net/publication/281267085_Burnout_and_ work_engagement_for_different_age_groups_Examining_ group-level_differences_and_predictors [accessed 4 March, 2020].

Halverson, R. R., \& Bliese, P. D. (1996). Determinants of soldier support for operation uphold democracy. Armed Forces and Society, 23(1), pp. 81-96.

Hardy, B. (2009). Morale: Definitions, dimensions and measurement. PhD dissertation, Cambridge Judge Business School, University of Cambridge. 
Herrera, C. J. (2012). Multicultural personality, hardiness, morale, distress and cultural stress in U.S. service members. PhD dissertation, University of Tennessee.

Higgins, E. T. \& Scholer, A. A. (2008). When Is Personality Revealed? A Motivated Cognition Approach. In L. A. Pervin \& O. P. John (Eds.), Handbook of Personality: Theory and Research (pp. 182-207). New York: The Higgins, E. T. \& Scholer, A. A. (2008). When Is Personality Revealed? A Motivated Cognition Approach. In L. A. Pervin \& O. P. John (Eds.), Handbook of Personality: Theory and Research (pp. 182-207). New York: The Guilford Press.

Houkes, I., Winants, Y., Twellaar, M., \& Verdonk, P. (2011). Development of burnout over time and the causal order of the three dimensions of burnout among male and female GPs. A three-wave panel study. BMC Public Health, 11, p. 240. doi: 10.1186/1471-2458-11-240.

Ilies, R., Fulmer, I. S., Spitzmuller, M., \& Johnson, M. D. (2009). Personality and citizenship behaviour: The mediating role of job satisfaction. Journal of Applied Psychology, 94(4), pp. 945-959.

Inceoglu, I., \& Warr, P. (2011). Personality and work engagement. Journal of Personnel Psychology, 10, pp. 177-181. doi: $10.1027 / 1866-5888 / \mathrm{a} 000045$.

Ingraham, L. H., \& Manning, F. J. (1981). Cohesion: Who needs it, what is it and how do we get it to them? Military Review, 61(6), pp. 2-12.

Ivey, G. (2014). How's morale? What is morale? In: Ivey, G., Sudom, K., Dean, W. H., \& Tremblay, M. (eds.), The Human Dimensions of Operations: A Personnel Research Perspective. Canadian Defence Academy Press, Kingston, pp. 1-24.

Ivey, G. W., Blanc, J.-R. S., \& Mantler, J. (2015). An assessment of the overlap between morale and work engagement in a nonoperational military sample. Journal of Occupational Health Psychology, 20(3), pp. 338-347.

James, J. B., McKechnie, S., \& Swanberg, J. (2011). Predicting employee engagement in an age-diverse retail workforce. Journal of Organizational Behavior, 32(2), 173-196.

Jex, S. M., \& Bliese, P. D. (1999). Efficacy beliefs as a moderator of the impact of work-related stressors: A multilevel study. Journal of Applied Psychology, 84(3), pp. 349-361.

Jonsson, E., Gustavsson, B., \& Carlstedt, B. (2010). Testing the Netherlands' morale survey for the Swedish armed forces. In: Presentation in Military Testing Association Annual Conference in Lucerne, Lucerne.

Judge, T. A., Heller, D., \& Mount, M. K. (2002). Five-factor model of personality and job satisfaction: A meta-analysis. Journal of Applied Psychology, 87(3), pp. 530-541.

Kasemaa, A., \& Säälik, Ü. (2021). The development of military morale measurement and its validation in the Estonian defence forces. Unpublished manuscript.

Kim, H. J., Shin, K. H., \& Swanger, N. (2009). Burnout and engagement: A comparative analysis using Big Five personality dimensions. International Journal of Hospitality Management, 28, pp. 96-104.

Kim, H. J., Shin, K. H., \& Umbreit, T. (2007). Hotel job burnout: The role of personality characteristics. International Journal of Hospitality Management, 26(2), pp. 421-434.

Lakens, D. (2013). Calculating and reporting effect sizes to facilitate cumulative science: A practical primer for t-tests and ANOVAs. Frontiers in Psychology, 4, p. 863. doi: 10.3389/ fpsyg.2013.00863.
Langelaan, S., Bakker, A. B., Van Doornen, L. J. P., \& Schaufeli, W. B. (2006). Burnout and work engagement: Do individual differences make a difference? Personality and Individual Differences, 40, pp. 521-532.

Lenhard, W., \& Lenhard, A. (2016). Calculation of effect sizes. Available at: https://www.psychometrica.de/effect_size. html. Dettelbach (Germany): Psychometrica. doi: 10.13140/ RG.2.2.17823.92329.

Mahboubi, M., Ghahramani, F., Mohammadi, M., Amani, N., Mousavi, S. H., Moradi, F., et al. (2014). Evaluation of work engagement and its determinants in Kermanshah hospitals staff in 2013. Global Journal of Health Science, 7(2), pp. 170-176. doi: 10.5539/gjhs.v7n2p170.

Manning, F. J. (1991). Morale, Cohesion and Esprit de Corps. In: Mangelsdorff, D. A., \& Gal, R. (eds.), Handbook of Military Psychology. John Wiley \& Sons Ltd, Chichester, pp. 451-470.

Manning, F. J. (1994). Morale and cohesion in military psychiatry. In Jones, F. D., Sparacino, L. R., Wilcox, V. L., \& Rothberg, J. M. (eds.), Military Psychiatry: Preparing in Peace for War. Falls Church: Office of the Surgeon General Department of the Army, USA, Virginia, pp. 1-19.

Maslach, C., \& Leiter, M. P. (1997). The Truth about Burnout: How Organizations Cause Personal Stress and What to do About it. Jossey-Bass, San Francisco, CA.

Maugen, S., \& Litz, B. T. (2006). Predictors of morale in U.S. peacekeepers. Journal of Applied Social Psychology, 36(4), pp. 820-836.

McCrae, R. R., \& Costa, P. T., Jr. (2008). The five-factor theory of personality. In: John, O. P., Robins, R. W., \& Pervin, L. A. (eds.), Handbook of Personality: Theory and Research. NY, London: The Guilford Press, pp. 159-181.

Milgram, A. N., Orenstein, R., \& Zafrir, E. (1989). Stressors, personal resources, and social supports in military performance during wartime. Military Psychology, 1(4), pp. 185-199.

Mischel, W., \& Shoda, Y. (2008). Toward a unified theory of personality. Integrating dispositions and processing dynamics within the cognitive-affective processing system. In John, O. P., Robins, R. W., \& Pervin, L. A. (eds.), Handbook of Personality: Theory and Research. The Guilford Press, New York, pp. 208-241.

Morgan, B., \& de Bruin, K. (2010). The relationship between the Big Five personality traits and Burnout in South African university students. South African Journal of Psychology, 40(2), pp. 182-191. doi: 10.1177/008124631004000208.

Motowidlo, S. J., \& Borman, W. C. (1977). Behaviorally anchored scales for measuring morale in military units. Journal of Applied Psychology, 62(2), pp. 177-183.

Motowidlo, S. J., \& Borman, W. C. (1978). Relationships between military morale, motivation, satisfaction, and unit effectiveness. Journal of Applied Psychology, 63(1), pp. 47-52.

Müürsoo, A. (2018). Kui vajalikuks peavad ajateenijad ajateenistust? Mõjutegurid ja hinnangu muutus teenistuse jooksul [How important is compulsory military service in the opinion of conscripts? Influencers and change of ratings during the service period]. Estonian Journal of Military Studies, 6, pp. 52-107.

Parmak, M. (2010). Morale and ethnicity in the military: Psychological coping with conscription in the Estonian Defence Forces. Occasional Paper. Tallinn: International Centre for Defence Studies. 
Parmak, M., Mylle, J. J. C., \& Konstabel, K. (2021). The soldiers' personality questionnaire: Validation of a short five-factor model instrument for the Estonian military. Unpublished manuscript.

Patrick, K., \& Lavery, J. F. (2007). Burnout in nursing. Australian Journal of Advanced Nursing, 24, pp. 43-48.

Peterson, C., Park, N., \& Sweeney, P. J. (2008). Group well-being: morale from positive psychology perspective. Applied Psychology: An International Review, 57, pp. 19-36.

Reed, B. J., Midberry, C., Ortiz, R., Redding, J., \& Toole, J. (2011). Morale: The essential intangible. In: Sweeney, P., Matthews, M., and Lester, P. (eds.), Leading in Dangerous Contexts. Annapolis: Naval Institute Press, pp. 202-217.

Ryff, C. D. (1989). Happiness is everything, or is it? Explorations on the meaning of psychological well-being. Journal of Personality and Social Psychology, 57(6), pp. 1069-1081. doi: 10.1037/0022-3514.57.6.1069.

Salanova, M., Bakker, A. B., \& Llorens, S. (2006). Flow at work: Evidence for an upward spiral of personal and organizational resources. Journal of Happiness Studies, 7, pp. 1-22, doi: 10.1007/s10902-005-8854-8.

Sawilowsky, S. S. (2009). New effect size rules of thumb. Journal of Modern Applied Statistical Methods, 8(2), pp. 597-599, doi: $10.22237 /$ jmasm/1257035100.

Schaufeli, W. B., \& Bakker, A. B. (2004). UWES Utrecht Work Engagement Scale Preliminary Manual. Utrecht: Occupational Health Psychology Unit Utrecht University.

Shamir, B., Brainin, E., Zakay, E., \& Popper, M. (2000). Perceived combat readiness as collective efficacy: individual- and group-level analysis. Military Psychology, 12(2), pp. 105-119.

Sharma, A., Goel, A., \& Sengupta, S. (2017). How does work engagement vary with employee demography? - Revelations from the Indian IT industry. Procedia Computer Science, 122, pp. 146-153. Elsevier B.V. doi: 10.1016/j.procs. 2017.11.353.

Siebold, G. L. (1999). The evolution of the measurement of cohesion. Military Psychology, 11(1), pp. 5-26.

Siebold, G. L. (2006). Military group cohesion. In: Britt, T. W., Castro, C. A., \& Adler, A. B. (eds.), Military Performance. Military Life: The Psychology of Serving in Peace and Combat: Military Performance. Westport (Conn.): Praeger Security International, pp. 185-201.

Sinclair, R. R., \& Tucker, J. S. (2006). Stress-care: An integrated model of individual differences in soldier performance under stress. In: Britt, T. W., Castro, C. A., \& Adler, A. B. (eds.), Military Life: The Psychology of Serving in Peace and Combat. Volume 1: Military Performance. Praeger Security International, Westport, CT, pp. 202-231.
Sonnenchein, M. (2007). Sick with Burnout Clarified Through Electronic Diaries. Gildeprint BV, Enschede, Netherlands.

Sonnentag, S., Dormann, C., \& Demerouti, E. (2010). Not all days are created equal: The concept of state work engagement. In: Bakker, A. B., \& Leiter, M. (eds.), Work Engagement: The Essential in Theory and Research. Psychology Press, New York, NY, pp. 25-38.

Steger, M. F., Littman-Ovadia, H., Miller, M., Menger, L., \& Rothmann, S. (2013). Engaging in work even when it is meaningless: Positive affective disposition and meaningful work interact in relation to work engagement. Journal of Career Assessment, 21(2), pp. 348-361. doi: 10.1177/1069072712471517.

Suzuki, Y., Tamesue, D., Asahi, K., \& Ishikawa, Y. (2015). Grit and work engagement: A cross-sectional study. PloS One, 10(9). doi: 10.1371/journal.pone. 0137501.

Switek, M. (2012). Life satisfaction in Latin America: A size-of-place analysis. Journal of Development Studies, 48(7), pp. 983-999. doi: $10.1080 / 00220388.2012 .658374$.

Tucker, S. J., Sinclair, R. R., \& Thomas, J. L. (2005). The multilevel effects of occupational stressors on soldiers' well-being, organizational attachment and, readiness. Journal of Occupational Health Psychology, 10(3), pp. 276-299.

Vaitkus, M., \& Griffith, J. (1990). An evaluation of unit replacement on unit cohesion and individual morale in the U.S. army all-volunteer force. Military Psychology, 2(4), pp. 221-239.

van Boxmeer, F., Verwijs, C., \& Euwema, M. (2011). Assessing soldiers' morale in challenging environment. Unpublished presentation in Annual International Military Testing Association Conference in Bali, 30th Oct-03rd Nov, 2011.

van Boxmeer, F., Verwijs, C., de Bruin, R., Duel, J., \& Euwema, M. (2007). A direct measure of morale in the Netherlands'armed forces morale survey: Theoretical puzzle, empirical testing and validation. In: Unpublished presentation in Annual International Military Testing Association Conference in Cold Coast, 8.-12. Oct 2007.

Whitesell, A. A., \& Owens, G. P. (2012). The impact of patriotism, morale, and unit cohesion on mental health in veterans of Iraq and Afghanistan. Traumatology, 18(1), pp. 1-7.

Xanthopoulou, D., Bakker, A. B., Demerouti, E., \& Schaufeli, W. B. (2009). Work engagement and financial returns: A diary study on the role of job and personal resources. Journal of Occupational and Organizational Psychology, 82(1), pp. 183-200. doi: 10.1348/096317908X285633.

Yildiz Durak, H., \& Saritepeci, M. (2019). Occupational burnout and cyberloafing among teachers: Analysis of personality traits, individual and occupational status variables as predictors. The Social Science Journal, 56(1), pp. 69-87, doi: 10.1016/j. soscij.2018.10.011. 